(C) Copyright 2019: Editum. Servicio de Publicaciones de la Universidad de Murcia. Murcia (Spain) ISSN print edition: 0212-9728. ISSN on line edition (http://revistas.um.es/analesps): 1695-2294. On line edition License Creative Commons 4.0: BY-NC-ND

\title{
Predictors of personality and self-efficacy of sexual risk behavior in Mexican adolescents
}

\author{
Jorge Palacios
}

Universidad del Valle de México, Querétaro (México)

\begin{abstract}
Título: Predictores de personalidad y autoeficacia sobre la conducta sexual en jóvenes mexicanos.

Resumen: Antecedentes: La presente investigación determina el nivel de predicción de la búsqueda de sensaciones y la autoeficacia sobre la conducta sexual de riesgo en jóvenes mexicanos. Se plantea que la búsqueda de sensaciones y la autoeficacia tienen una incidencia combinada en el comportamiento sexual de riesgo de los jóvenes. Método: Se midieron la búsqueda de sensaciones y la autoeficacia con dos escalas diferentes en una muestra no probabilística de 1012 jóvenes, entre 14 y 22 años, de la Ciudad de México. Resultados: mostraron tres facetas de la búsqueda de sensaciones y dos dimensiones de la autoeficacia, tienen una incidencia directa en la conducta sexual de riesgo de los jóvenes consistente con la hipótesis postulada y que en combinación explican el $19.2 \%$ de la varianza. Conclusiones: considera el efecto combinado de la búsqueda de sensaciones y la autoeficacia, así como las implicaciones prácticas para la elaboración de programas preventivos sobre la conducta sexual de riesgo en los jóvenes.

Palabras clave: Personalidad; Búsqueda de sensaciones; Autoeficacia y conducta sexual de riesgo.
\end{abstract}

\section{Introduction}

The sexual behavior of people, where access to sexual and reproductive health services can make the difference between sexuality being exercised freely and responsibly, or stop taking necessary actions to reduce the risk of having a pregnancy not planned or acquiring a sexually transmitted infection (STI). ENADID (2014), reports that of the total of women from 15 to 49 years of age, $51.6 \%$ declare use some contraceptive method, it should be noted that $66.9 \%$ of the young women between 15 and 19 years old, use contraceptive methods not hormonal. At national level, the median age at the beginning of the sexual life of women is at 18 years. For the group of 15 to 19 years old, $54.5 \%$ of the women reported having used, she or her partner, some method of protection in their first sexual relationship.

According to the CONAPO (2016), women between 25 and 34 years had their first sexual encounter at 17.7 years. The pattern of sexual behavior in Mexican adolescents shows that $23 \%$ have had sex; with a sustained increase in the proportion of sexual activity in men and women aged 12 to 19 years. Adolescents who started their sex life without protection were $33.4 \%$ in the case of women and $14.4 \%$ in men. The average age of first intercourse is 15.7 years. The contraceptive method most frequently used in adolescentes is the condom (80.6\%), (National Health and Nutrition Survey [ENSANUT], 2012; González, Rojas, Hernández and Olaiz,

* Correspondence address [Dirección para correspondencia]: Jorge Raúl Palacios Delgado. Blvd. Juriquilla no. 1000 A Del. Santa Rosa Jáuregui / CP 76230 / Querétaro, México.

E-mail: jorge.palaciosd@uvmnet.edu

(Article received: 25-1-2018; revised: 30-5-2018; accepted: 12-6-2018)
Abstract: Background: This research determines the level of prediction of sensation seeking and self-efficacy on sexual risk behaviors in young Mexicans. The sensations seeking and self-efficacy have a combined impact on the risk sexual behaviors of young people. Method: The sensation seeking and selwef-efficacy were measured with two different scales in a nonprobabilistic sample of 1012 young people, between 14 and 22 years old, from Mexico City. Results: showed that three facets of the sensation seeking and two dimensions of self-efficacy have a direct incidence in the sexual risk behavior of young people consistent with the postulated hypothesis and that in combination explain $19.2 \%$ of the variance. Conclusions: consider the combined effect of the search for sensation seeking and selfefficacy, as well as the practical implications for the development of preventive programs on sexual risk behavior in young people.

Keywords: Personality; Sensation seeking; Self-efficacy and risky sexual behavior.

2005). Considering the age of initiation of sexual activity and the use of contraceptive methods used by young people, indicate that they will have a longer period of exposure to the risk of pregnancy or of acquiring an STI.

Although from the year 2000 condom use has increased in our country, in a sample of adolescents, only $42.3 \%$ have always used condoms in their sexual relations (Palacios, Bravo \& Andrade, 2007), for its part, Rodríguez, Paniagua, Montijo, Villegas, Arroyo and Cervantes, (2008), report that $60 \%$ of middle and high school students, with an average age of 16 years old, used a condom in their first sexual relationship, $44 \%$ planned it, $53 \%$ proposed condom use, and 55\% were their partner proposed it. Recently in another study (Alvarado, Salinas \& Martínez, 2017), it was found that $77.8 \%$ of young people in Chiapas and $81 \%$ of the sample of young people in Colima did not use a condom in their first sexual relationship, which indicate that most of the sexual behaviors, mainly among adolescents and young adults, it is unprotected that leads them to engage in risky sex (Beadnell et al., 2005; Capaldi, Stoolmiller, Clark \& Owen, 2002; Fishbein, 2000; Jiménez, Andrade, Betancourt \& Palacios, 2007; Palacios, Andrade \& Bravo, 2008).

Regarding sexual risk behavior in young people, there are some factors that contribute to this behavior, among which the personality stands out as one of them. Within the personality traits one of the most empirical evidence regarding risk behaviors is the sensations seeking (Hansen \& Breivik, 2001; Palacios, Sánchez \& Andrade, 2010; Roberti, 2004; Rosenbloom, 2003).

The seeking sensations is a personality trait that is defined as the need to seek and experience new, varied, complex and intense experiences and sensations, and as the desire to engage in physical and social risks, for the simple desire to 
enjoy such experiences (Zuckerman, 1994). The term seek refers to a trait that is actively expressed and sensation refers the sensory effect of external stimulation, which is very important to define its value as a primary reinforcer, that is, the external stimulus maximize sensations (Zuckerman, 1979, 1994).

The people who seeks sensations is characterized by unusual actions, which would be dangerous and risky, which depends on how each person values the risk, that is to say, the probability that an action has negative results (Zuckerman, 1979; Zuckerman \& Kuhlman, 2000). A person with a high sensation seeking is characterized by his or her tendency to do those things that a person with low sensation search considers dangerous and risky. The difference between them is the different assessment of risk (Horvath \& Zuckerman, 1993; Palacios \& Cañas, 2010; Zuckerman et al., 2000). The sensations seeking is considered a multifaceted trait, with at least four components: seeking for emotion and adventure (SAC), seeking for experiences (ES), disinhibition (Dis) and susceptibility to boredom (BS) (Zuckerman, 1971, 1994).

Recently, it has been found that the sensations seeking have some influence on the sexual risk behavior of adolescents. For example, sensation seekers engage in a variety of risk sexual behaviors (e.g. number of sexual partners, decreased condom use, and the risk of acquiring a Sexually Transmitted Infection) (Zuckerman, 1994). González, Vassileva, Bechara, Grbesic, Sworowski, Novak, Nunnally \& Hielen (2005), found that the sensations seeking was associated with a greater number of sexual partners. On the other hand, Spitalnick et al, (2007), found that adolescents with high levels of sexual sensation seeeking reported greater risky sexual behavior (i.e. frequency of sexual intercourse, number of sexual relations, and low condom use).

Hoyle, Fejfar and Miller (2000) mention that the seeking sensations is positively related to sexual risk behavior (number of sexual partners, unprotected sex and high-risk encounters). In addition, Bancroft, Jansens, Carnes, Goodrich, Strong \& Long (2004) identified that disinhibition is a predictor of sexual relationships and number of sexual partners. In the same direction, Zuckerman, (2007) reports that the sensations seeking is related to the frequency of sexual relations, number of couples, unprotected sexual activity and condom use. Finally, Bancroft, Carnes \& Janssen, (2005), point out that a greater sensations seeking was found in men who had unprotected anal sex and who were HIV infected.

In addition, there is evidence that explains the association of sensation seeking and risky sexual behavior among people who have consumed some kind of addictive substance. For example, Donohew, Zimmerman, Cupp, Novak, Colon and Abell, (2000), found a high sensations seeking in people who have consumed alcohol and marijuana before having sex and who have unprotected sex when consuming alcohol, and also express the intention to have sex in the future. Kalichman \& Cain (2004), mention that the sensations seeking affect unprotected sexual activity and expectations for alcohol consumption.
About the sociocognitive factors, self-efficacy has been shown to be a relevant determinant for understanding healthy behaviors (Luszczynska, Sheng, Mallach, Pietron, Mazurkiewicz \& Schwarzer, 2010; Palacios \& Ramírez, 2016; Palacios, Ramírez, Anaya, Hernández \& Martinez, 2017; Wilson-Barlow, Hollins \& Clopton, 2014). Self-efficacy refers to the individual's ability to handle life situations appropriately (Bandura, 1997) and it can influence both feelings, thoughts and actions. In terms of action, people who feel effective, have higher goals and persist more in their purposes compared to those who do not have strong personal control (Bandura, 1977, 1997). The cognitive factors are immediate and specific precursors of behavior (Bandura, 2001; Palacios \& Bustos, 2012a; Palacios \& Bustos, 2013a). The cognitive dimensions affect a particular behavior and the adoption of a particular course of action (Palacios, 2011; Palacios \& Bustos, 2012b).

According to the theory of social learning or cognitive social learning (Bandura, 1977, 1987, 1994, 2001), selfefficacy (Bandura, 1994, 1997) varies significantly between different situations and tasks that individuals have about their ability to act. Previous studies linking self-efficacy to risky sexual behavior describe that those who are more selfefficacious reject having unprotected sex and have a greater intention to use condoms (Sanderson \& Yopyk, 2007). The Authors O'Leary, Jemmott and Jemmott III (2008), mention that self-efficacy to wear a condom and self-efficacy to use it are significant factors in condom use behavior. KoniakGriffin and Stein (2006) point out that increased self-efficacy predicts intentions to use condoms and have protected sex. In contrast, Chewning, Douglas, Kokotailo, La Court, Clair, Spec \& Wilson, (2001) describe that high self-efficacy was associated with abstinence from intercourse and consistent condom use.

Diiorio, Dudley, Nelly, Soet, Mbwara and Sharpe (2001) point out that adolescents who expressed confidence in using a condom, refusing to have sex with a new sexual partner, and those with higher expectations associated with condom use were more likely to use condoms consistently. Finally, Lindberg (2000) found a significant relationship between the self-efficacy of using condoms and the behavior of using them in women who engage in risky behaviors that include having multiple sexual partners, sexually exposed partners and unprotected sex.

Additionally, it has been found that those who have a higher degree of self-efficacy are more prone to refuse unprotected sex and are more likely to use condoms in new sexual relationships (Palacios \& Parrao, 2010). Robles, Piña, Frías, Rodríguez, Barroso and Moreno (2014), show that men have less ability to refuse to have sex than women and only in these women self-efficacy is the best predictor of inconsistent condom use behavior when having vaginal intercourse. Recently Estrada, Campero, Suárez, Vara and González, (2017), find that $61.6 \%$ of adolescents are perceived to have a high capacity for the correct use of condoms, half to talk with their partner about ways to prevent pregnancy or 
STI and $32.8 \%$ of men they have very high capacity to refuse to have sex without a condom. Later Alvarado, Garzón, Cruz, Sierra, Peña and Muñetón, (2017), find that for the frequency of condom use in sex life; their results indicate that in men the perception of self-efficacy predicts $10 \%$ the frequency of condom use; in the group of women, however, no predictive model of the frequency of condom use in sexual relationships was generated.In addition, when appropriate condom use es taught to teenagers, the correct use of the condom is teaching to the young, they increase their selfefficacy to buy and use condoms, increasing the percentage of correct answers to the steps to use and to place a condom (Cabrera, Olvera \& Robles, 2006; Torres \& Diaz-Loving, 1999).

Considering that sexual behavior among adolescents has an increasing number of health risks associated with having sexual activity at a younger age, not using condoms and with negative consequences including sexually transmitted infections such as Human Immunodeficiency Virus, Human Papilloma Virus or unwanted pregnancies.

Although previous research has identified personality and sociocognitive factors that influence sexual risk behavior, its approach has been made by analyzing each factor separately, so there are few studies that incorporate both variables as a whole, to predict the incidence they may have on adolescent risk behavior. Previous research has consistently emphasized that the sexual sensation seeking exhibits a direct relationship with less condom use and a greater number of sexual partners (Noar, Zimmerman, Palmgreen, Lustria \& Lee, 2006) in addition when young people have a lower self-efficacy to use condoms, the probability of engaging in risky sexual behaviors increases (Sayles et al., 2006), thus estimating the incidence of antecedent behavioral sexual risk factors, will allow them to be used in prevention and intervention programs that can be developed and implemented to reduce adolescent risky sexual behavior.

Based on the above, the aim of the current research effort is to determine the prediction of sensation seeking and self-efficacy on risky sexual behavior in a sample of young Mexicans.

Considering the existing theoretical and empirical background, the present study emerges from socio-behavioral proposals (Noar et al., 2006; Palacios \& Parrao, 2010) that facilitate the incorporation of personality traits such as sensation seeking (Hansen \& Breivik, 2001; Roberti, 2004; Zuckerman, 1994, 2007) and cognitive social theory cognitiva (Bandura 1977, 1994, 2001). The hypothesis propoused that sensations seeking has a direct impact on sexual risk behaviors and self-efficacy will be a positive promoter for protected sexual behavior, both factors will have a combined effect on young people's risky sexual behavior.

\section{Method}

\section{Sample}

A non-probabilistic and intentional sample of 1012 high school student, 531 men and 481 women, aged $14-22$ years old and mean of 16.47 years $(S D=1.2)$, were selected from three public high schools in Mexico City. The first semester were $32.2 \%$, third semester were $24.3 \%$ and fifth semester were $43.5 \%$.

\section{Measures}

Sexual risk behavior refers to behavior that may compromise an individual's well-being, health and life in progress, with negative outcomes or adverse consequences for each person, including age of onset of sexual activity, frequency of sexual intercourse, total number of sexual partners in lifetime, use of condoms and number of STIs reported by young people. The measurement performed has been tested in several studies in Mexican samples (Palacios, et al., 2007; Palacios et al., 2008; Palacios \& Parrao, 2010).

To measure personality, we used the Sensation Seeking Inventory (Palacios, 2015a), composed of 104 items. It is a Likert type scale with four options of answer (never to always) that measures 8 facets of this personality trait: pleasure seeking (eg, I look for pleasant things), risk seeking (eg, I like to do risky things), emotions seeking (eg, I like strong emotions), novelty seeking (eg, I like to live new experiences), seeking for experiences and adventure (eg, I would like to explore strange places), disinhibition (eg, I enjoy the company of uninbibited people), unusual seeking (eg, dressing up in an extravagant style) boredom susceptibility (eg, I get bored if I have to be at home). The scale has construct validity, predictive with multiple risk behaviors and criterion between men and women. It has an adequate internal consistency according to Cronbach's Alpha Coefficient of $.88(95 \% \mathrm{CI}=.86-.89)$.

To evaluate self-efficacy of risk behaviors, the instrument Palacios (2015a) was used to measure the ability to avoid or reject five risk behaviors: substance use self-efficacy: alcohol (eg, I am efficient to refuse to consume alcohol), tobacco (eg, I am efficient to refuse to consume tobacco), and drugs (eg, I am efficient to refuse to use drugs), sexual intercourse self-efficacy (eg, I would be efficient to refuse sex if I do not have condoms) self-efficacy to avoid harm to health (eg, I avoid doing things that damage my health) and antisocial behavior self-efficacy (eg I am efficient to avoid engaging in quarrels or fights). The instrument consists of 43 items with response type Likert from almost never to almost always. The instrument has factorial construct validity and predictive validity with each risk behavior that evaluates the instrument, as well as, a Cronbach Alpha reliability for the total instrument of $.95(95 \% \mathrm{CI}=.94-.95)$. 


\section{Procedure}

The information was obtained in two months. The instruments were applied to the adolescents in a group, using the school groups for this purpose, in addition, they were asked to respond to a questionnaire elaborated to know some activities that young people realize. They were told that their participation was voluntary and that the information was anonymous, for which they were asked to respond honestly, explaining that their responses would be used for research purposes.

\section{Ethical considerations}

All participants were informed that the information was anonymous, and the confidentiality of the data provided was guaranteed. The informed consent of participants and school authorities was used. The research protocol was established according to the Regulation of the General Health Law, in its section on research in human (Secretaría de Salud, 2011).

\section{Data analyses}

The data analyses were performed considering the descriptive statistics of sexual risk behavior. Subsequently, Spearman's Rho correlation analysis were performed among the variables involved in risky sexual behavior. Finally, different successive stepwise regression analyzes were performed to evaluate the effect of self-efficacy and sensation seeking on the sexual risk behavior of young people.

\section{Results}

The sexual behavior of youth participants in the study, it was found that $51.6 \%$ have started their sexual activity. The type of sex with that young people have are vaginal (38.1\%), vaginal and oral $(34.5 \%)$, vaginal, oral and anal $(18.8 \%)$. The average age of onset at which adolescents begin their sexual life is at 15.14 years old $(S D=1.5 ;$ Range $=11-20)$. The frequency with have sexual activity show in Table 1 . The number of sexual partners reported by adolescents was $3.4(S D=3.8)$ and the modal sexual partner number was 1 couple (Range $=$ $1-30)$.

Table 1. Distribution of frequency of sexual behavior.

\begin{tabular}{lcc}
\hline & Frequency & Percent \\
\hline I do not have sex & 493 & 48.7 \\
I only did it once & 139 & 13.7 \\
Once or twice a month & 226 & 22.3 \\
Once or twice every 15 days & 74 & 7.3 \\
Once or twice a week & 62 & 6.1 \\
Daily or almost daily & 18 & 1.8 \\
\hline
\end{tabular}

The condom use reported is $40.6 \%$ always used condoms in their sexual relations (Table 2). Young people report that $4.8 \%$ have had a Sexually Transmitted Infection (STI) and $0.2 \%$ have had two or more STIs in their lifetime. The reported STIs are: vaginitis $(16 \%)$, rash $(12 \%)$, papilloma $(8 \%)$, urinary tract infection $(8 \%)$, irritation $(4 \%)$ and herpes $(4 \%)$.

Table 2. Descriptive analysis of condom use in young people

\begin{tabular}{lcc} 
& Frequency & Percent \\
\hline Never & 32 & 6.1 \\
Hardly ever & 30 & 5.7 \\
Rarely & 86 & 16.5 \\
Most of the time & 162 & 31.0 \\
Always & 212 & 40.6 \\
\hline
\end{tabular}

In order to analyze the association between sexual risk behaviors, we performed multivariate Spearman Rho correlations. Table 3 shows the behaviors that correlate significantly. The age of onset of sexual relations correlates negatively and significantly with the frequency of sexual relations and with the number of sexual partners. The frequency with which they have sex correlates negatively with condom use, positively with the number of sexual partners and with the number of STIs.

Table 3. Correlations of sexual risk behavior.

\begin{tabular}{|c|c|c|c|c|c|}
\hline & 1 & 2 & 3 & 4 & 5 \\
\hline 1. Age of onset & $\begin{array}{ll}-- \\
--\end{array}$ & $-.145^{* *}$ & .076 & $-.472^{* *}$ & -.034 \\
\hline 2. Frequency of sexual intercourse & & --- & $-.285^{* *}$ & $.329^{* *}$ & $.188^{* *}$ \\
\hline 3. Condom use & & & --- & -.068 & -.076 \\
\hline 4. Number of sexual partners & & & & --- & .059 \\
\hline 5. Sexually Transmitted Infections & & & & & --- \\
\hline
\end{tabular}

5. Sexually Transmitted Infections

$* p<.05 * * p<.01 * * * p<.001$

In order to obtain the metric equivalence of sexual risk behavior responses (age of onset of sexual activity, frequency of sexual intercourse, condom use and number of sexual partners) were transformed to standardized scores to obtain normal distribution and to have an indicator that will integrate sexual risk behavior into a single variable. Subsequent, three different multiple stepwise regression analyzes were performed, considering as a criterion variable the indicator of sexual risk behavior and as predictors the eight facets of the seeking sensations, as well as the dimensions of selfefficacy risk behaviors.

The first regression analysis considering only the sensation seeking, showed three independent and significant predictors in regression model. In the first step the seeking pleasure $F_{(1,1010)}=134.96, p<.001$, was the main predictor. In the second step, the intense emotions seeking was incor- 
porated into the regression equation $F_{(2,1009)}=70.90, p$ $<.001$, and for the third step, the seeking of experiences and adventure was added $F_{(3,1008)}=49.21, p<.001$. These three traits of sensation seeking explain $12.7 \%$ of the variance of young people's sexual risk behavior.

The second regression analysis was integrated exclusively to self-efficacy against risk behaviors. The results showed four independent and significant predictors that entered the regression model. In the first step entered sexual self-efficacy
$F_{(1,1010)}=120.45, p<.001$, as the best predictor. In the second step, tobacco self-efficacy was incorporated into the regression equation $F_{(2,1009)}=69.78, p<.001$. In the third step, self-efficacy was added to antisocial behavior $F_{(3,1008)}=$ $48.89, p<.001$, and alcohol consumption self-efficacy was added as the last step $F_{(4,1007)}=37.93, p<.001$. The four selfefficacy factors account for $13.1 \%$ of the variance of young people's sexual risk behavior in this sample (see Table 4).

Table 4. Multiple stepwise regression analysis to predict sexual risk behavior, from each independent variable.

\begin{tabular}{|c|c|c|c|c|}
\hline & $B$ & SE B & $\beta$ & IC 95\% \\
\hline \multicolumn{5}{|l|}{ Sensation seeeking } \\
\hline 1. Pleasure seeking & 1.53 & 0.16 & $0.33^{* * *}$ & $1.20-1.86$ \\
\hline 2. Emotions seeking & 0.52 & 0.16 & $0.12^{* *}$ & $0.20-0.84$ \\
\hline 3. Seeking for experiences and adventure & -0.41 & 0.18 & $-0.08 *$ & $-0.78--0.40$ \\
\hline \multicolumn{5}{|l|}{ Self-efficacy of risk behaviors } \\
\hline 1. Sexual self-efficacy & -1.31 & 0.14 & $-0.30 * * *$ & $-1.59--1.02$ \\
\hline 2. Tobacco self-efficacy & -0.37 & 0.14 & $-0.10 * *$ & $-0.65--0.09$ \\
\hline 3. Antisocial behavior & 0.57 & 0.20 & $0.09 * *$ & $0.17-0.96$ \\
\hline 4. Alcohol self-efficacy & -0.31 & 0.14 & $-0.08^{* *}$ & $-0.61--0.02$ \\
\hline
\end{tabular}

Finally, in order to analyze the predictive capacity of the sensation seeking and self-efficacy for risk behaviors in combination, on the risk of sexual behavior, a third regression model was performed step by step in an additional way. The dependent variable used was the indicator of sexual risk behavior and as independent variables we considered the eight facets of the seeking sensations and the six dimensions of self-efficacy against risk behaviors (See Table 5). The results showed five independent and significant predictors that entered the regression model. In the first step entered the seeking pleasure $F_{(1,1010)}=134.96, p<.001$, as the most im- portant predictor in sexual risk behavior. In the second step, sexual behavior self-efficacy was incorporated in the regression equation $F_{(2,1009)}=105.82, p<.001$. In the third step, tobacco self-efficacy was incorporated into the regression mo$\operatorname{del} F_{(3,1008)}=75.373, p<.001$. In the fourth step the intense emotions seeking $F_{(4,1007)}=58.34, p<.001$, was added and the seeking for experiences and adventure was added as the last step $F_{(5,1006)}=47.78, p<.001$. The five combined factors considered as predictors explain $19.2 \%$ of the variance of young people's sexual risk behavior in this sample.

Table 5. Multiple stepwise regression analysis to predict sexual risk behavior in combined form.

\begin{tabular}{|c|c|c|c|c|}
\hline & $B$ & $S E B$ & $\beta$ & IC 95\% \\
\hline 1. Pleasure seeking & 1.157 & 0.16 & $.249 * * *$ & $.826-1.48$ \\
\hline 2. Sexual self-efficacy & -.940 & 0.13 & $-.217 * * *$ & $-1.202--.678$ \\
\hline 3. Tobacco self-efficacy & -.374 & 0.11 & $-.101 * *$ & $-.593--.156$ \\
\hline 4. Emotions seeking & .501 & 0.15 & $.118^{* *}$ & $.193-.808$ \\
\hline 5. Seeking for experiences and adventure & -.395 & 0.18 & $-.083^{*}$ & $-.752--.037$ \\
\hline
\end{tabular}

5. Seeking for experiences and adventure

\section{Discussion}

The results obtained regarding the age of the onset the sexual behavior is similar to that found in other studies (ENADID, 2014; ENSANUT, 2012; Jiménez, et al., 2007; Palacios, et al., 2007 Rodríguez, et al., 2008). The early onset of sexual activity is a risk factor for the number of sexual partners, it follows that prevention programs should be geared to implementation at an earlier age, such as middle education. The number of sexual partners supports the findings of previous studies (Alvarado, et al., 2017; González, et al., 2005; Palacios, et al., 2007; Palacios, et al., 2008). Low condom use (about 59.4\% have not always used it) puts these young people at high risk, since it is necessary to always use condoms during sexual intercourse, whether vaginal, oral or anal, to reduce the possibility of acquiring an STI.

The structure of risky sexual behavior has been represented by the age of onset of sexual life, number of sexual partners, frequency of sexual intercourse, condom use and the likelihood associated with STI transmission. This composition has shown that it is possible to be approached in this research as indicated by previous studies (Beadnell, et al., 2005; Capaldi, et al., 2002; Palacios, et al., 2007; 2008), finding a certain pattern of covariation of different risk behaviors. Under this scheme, the results show that the age of onset of sexual relations is related to the frequency of sexual intercurse and to the number of sexual partners, together with the increase in the frequency of sexual relations, the number of 
sexual partners, the use of condoms decreases and the presence of STIs increases, thus placing young people in behaviors that endanger their health and their life in progress, therefore, to verify in which sense of personality and sociocognitive factors contribute to adolescents presenting a lower number of risk behaviors is an important element in the development of prevention programs aimed at reducing the spread of STIs such as HIV, HPV and the reduction of unplanned pregnancies.

Regard to the factors identified as personality traits that affect sexual risk behavior, the incidence of sensation seeking in the prediction and explanation of sexual risk behavior has been corroborated. The results are in agreement with the findings of other studies (Bancroft, et al., 2004; Donohew, et al., 2000; Hoyle, et al., 2000; Kalichman \& Cain, 2004; Noar, et al., 2006; Spitalnick, et al., 2007), stating that those with high levels of sensation seeking perform risky sexual behavior. This means that young Mexicans who seek excitement and pleasure, stimulate their senses by experiencing intense emotions, and engage in unknown experiences, are those who engage in more risky sexual behaviors (they have begun their sexual activity at a younger age, frequency of intercourse, maintain more sex partners and have poor condom use).

The important effect of self-efficacy to prevent the presence of risk behaviors has been confirmed (Bandura, 1994; Lindberg, 2000; Palacios, 2015b), identifying the predictors that are presented to reduce the presence of risky sexual behaviors. The evidence found supports the findings of studies that incorporate self-efficacy as precursors of sexual risk behaviors (Cabrera, et al., 2006; Chewning, et al., 2001; Diiorio, et al., 2001; Estrada, et al., 2017; Koniak-Griffin \& Stein, 2006; Lindberg, 2000; O'Leary, et al., 2008; Palacios \& Parrao, 2010; Sanderson \& Yopyk, 2007; Sayles et al., 2006), indicating that adolescents who are more self-efficacious refuse unprotected sex, express confidence in using condoms in their next sexual relationship, are opposed to engaging in risky behaviors that include having multiple sexual partners with sexual risk and having less unprotected sex.

An element that seems interesting in the findings found here is that in addition to the self-efficacy to reject risky sexual behaviors, self-efficacy to refuse to consume tobacco and alcohol predict a lower risk sexual behavior, but not selfefficacy against antisocial acts that is a promoter of sexual risk behavior. In other words, young people who have the ability to refuse sex without using condoms, use directed actions to refuse to have sex if they are proposed, as well as having the ability to avoid smoking and alcohol, refusing to participate in activities, places, contexts or situations in which it is consumed, as well as being in the presence of friends who use tobacco and alcohol without doing so, using actions directed to refuse to consume this type of substances, but do not have the capacity to refuse a participate in activities that involve being involved in some type of risk. So that evidence is provided in favor of pointing out that to the extent that specific abilities are encouraged in behavior (eg. to reject unprotected sexual behaviors), increases the proba- bility of increasing other specific abilities (eg. avoiding alcohol consumption) as previously reported (Palacios, 2015b).

In addition, the findings found provide evidence for the integration of cognitive social theory (Bandura, 1977, 1987, 2001) and self-efficacy in particular (Bandura 1977, 1997; Palacios, 2015b) in predicting risky sexual behavior. This suggests that self-efficacy is a fundamental and essential component in prevention programs for risk sexual behavior and in promoting the consistent use of condoms. Under this line, in my personal view, efforts to prevent risk behavior among adolescents using intervention programs need to be based on social cognitive theory and self-efficacy, so that with its implementation it can contribute and achieve a change in the ability to regulate behavior if it is acted upon. To do this, it is necessary to possess and develop certain capacities that need to be put into practice effectively and consistently under the circumstances they demand. Success will then depend on the control ability the person feels they have to perform behavior that prevents them from engaging in risky sexual situations.

The relevance and contribution of the research carried out is based, on the one hand, on obtaining the predictors of both the sensation seeking and self-efficacy independently in Mexican adolescents and on the other, perhaps the most relevant is the combined incorporation of the sensation seeking and self-efficacy in risky sexual behavior. In agreement with the presented hypothesis, the results indicated that the sensations seeking is an important predictor of the risk sexual behavior, inversely the self-efficacy is a primordial determinant in to avoid or to delay the presence of risk behaviors of sexual type, the combined effect high sensations seeking and low self-efficacy are positioned as determinants to present sexual risk in young people, conversely, the ideal combination to prevent this type of behavior is a low sensation seeking and greater self-efficacy, so interventions should use this idea if they are to increase the likelihood of preventive success in young people.

The findings of this research allowed us to identify the combined effect of sensation seeking and self-efficacy, as well as its direct incidence on sexual risk behavior and the courses of action of individuals to choose risky behavior or not (Bandura, 2005) that may affect its future life, in order to follow up on what was found in the present study and as a line of research to be followed in the short term, an investigation is being carried out that deepens the findings found, achieving the integration of a model that adds dispositional determinants, neuropsychological and psychosocial, under a neurocognitive approach that allows to estimate the joint interaction of these factors with the purpose of equipping young people with capacities or resources to use in the face of the possible consequences of risky sexual behavior such as STIs (HPV and HIV) and unplanned pregnancies, that is to say, prevent sexual risk behaviors.

Is important to note that the study has some limitations that must be taken into consideration. The first is about the sample size of adolescents who have had sexual activity, sin- 
ce it is small and it is only from Mexico City, so for future studies it will have to be expanded and take into account that these results they can not be generalized to the entire population, but reflect what is happening with a sample of Mexican adolescents. Consider the sample size obtained, it seems convenient that in order to corroborate the results obtained, the study should be replicated in larger samples from different cities. The second limitation corresponds to level of measurement of risky sexual behavior, since only five sexual risk behaviors were investigated, for future studies it should include the type of sexual activity, sexual preference, situations to not use a condom, intention to use a condom and the use of condoms in their last sexual relationship, in order to broaden the characterization of adolescents who engage in sexual risk behavior. Third, measures of sexual risk behavior relied on adolescent self-report, it is possible that adolescents under or over reported their sexual behaviors, however, youth responses in this sample were compared with results of nacional surveys. Fourth, other behavior risk and other psychological constructs of the nomological network can be used to obtain evidence of convergent and discriminant validity of mexican sensation seeking scale and self- efficacy scale. Fifth, this study not permit causal inferences regarding the

\section{References}

Alvarado, J. I. U., Garzón, M. E. R., Cruz, N. J. B., Sierra, S. M. C., Peña, Y. H., \& Muñetón, M. J. B. (2017). Percepción de autoeficacia vs. rechazo del uso del condón en las prácticas sexuales de mujeres y hombres jóvenes. Psicogente, 20(37), 25 - 35.

Alvarado, J. I. U., Salinas, X. Z., \& Martínez, J. L. C. (2017). La conducta sexual de adolescentes. Lacandonia, 5(2), 135-140.

Bancroft, J., Carnes, L. \& Janssen, E. (2005). Unprotected anal intercourse in HIV-Positive and HIV-Negative gay man: The relevance of sexual arousability, mood, sensation seeking, and erectile problems. Archives of Sexual Behavior, 34 (3), 299- 305.

Bancroft, J., Jansens, E., Carnes, L. Goodrich, D., Strong, D. \& Long, S. (2004). Sexual activity and risk taking in young heterosexual men: the relevance of sexual arousability, mood, and sensation seeking. The Journal of Sex Research, 41 (2), 181- 192.

Bandura, A. (1977). Self-efficacy: Toward a unifying theory of behavioral change. Psychological Review, 84, 191- 215.

Bandura, A. (1987). Pensamiento y acción: fundamentos sociales. Barcelona: Martínez Roca.

Bandura, A. (1994). Social cognitive theory and exercise of control over HIV infection. In: DiClemente, R. J. and Peterson, J. L. (Eds.). Preventing AIDS theories and methods of behavioral interventions (pp. 89-116). New York: Plenum Press.

Bandura, A. (1997). Self-efficacy: the exercise of control. New York: W.H. Freeman.

Bandura, A. (2001). Social Cognitive Theory: An agentic perspective. Annual Review of Psychology, 52, 1-26.

Beadnell, B., Morrison, D. M., Wildson, A., Wells, E. A., Murowchick, E., Hoppe, M., Rogers, G. M. \& Nahom, D. (2005). Condom use, frequency of sex, and number of partners: multidimensional characterization of adolescent sexual risk-taking. Journal of Sex Research, 42, (3), 192202.

Cabrera, A. A., Olvera, L. M. \& Robles, M. S. (2006). Entrenamiento en el uso correcto del condón y su relación con la autoeficacia percibida para usarlo [Training in the correct use of the condom and relation to the perceived self-efficacy to use it]. En: Sánchez, A. R., Díaz-Loving, R. \& Rivera, A. S. (Eds.). La Psicología Social en México (pp. 205- 211), Vol. XI, México: AMEPSO. relationships of sensation seeking and self efficacy on sexual riesk behavior. Causal direction involves in part the establishment of temporal precedence between psicological factors and sexual risk behavior. Finally, it is possible that identifying the influence of sensations seeking and self-efficacy on risk behaviors performed by young people, it is possible to confirm the findings obtained in this study in a path analyses model that includes other factors that have been studied, such as behavioral intention of condom use, attitudes or sexual motivation and that are important in sexual risk behavior.

Considering the results found, it is concluded that the ease in which young people can acquire a Sexually Transmitted Infection (STI) including HPV and HIV, or have unplanned pregnancies due to inconsistency in the correct use of the condom, can be determined by the combination of personality traits such as the sensation seeking and a lower selfefficacy to avoid sexual risk behaviors, because they are factors that intervene in healthy behaviors within the behavior of adolescents and have an important role in creating prevention programs and the reduction for sexual risk behavior in the adolescent.

Capaldi, D., M., Stoolmiller, M., Clark, S. \& Owen, D. (2002). Heterosexual risk behavior in at-risk young men from early adolescence to young adulthood: prevalence, prediction, and association with STD contraction. Developmental Psychology, 38, 394-406.

Chewning, B., Douglas, J., Kokotailo, P., La Court, J., Clair, D., Spec, M. \& Wilson, D. (2001). Protective factors associated with American Indian Adolescents' safer sexual patterns. Maternal and Child Health Journal, 5, 273- 280

Consejo Nacional de Población [CONAPO]. (2016). Situación de la Salud Sexual y Reproductiva en la República Mexicana. México: Consejo Nacional de Población.

Diiorio, C., Dudley, W., Nelly, M., Soet, J., Mbwara, J. \& Jennifer Sharpe Potter, J. S. (2001). Social cognitive correlates of sexual experience and condom use among 13- through 15-year-old adolescents. Journal of Adolescent Health, 29 (3), 208-216.

Donohew, L., Zimmerman, R., Cupp, P., Novak, S. Colon, S. \& Abell, R. (2000). Sensation seeking, impulsive decision- making and risky sex: implications for risk- taking and design of interventions. Personality and Individual Differences, 28, 1079- 1091.

Encuesta Nacional de la Dinámica Demográfica [ENADID], (2014). Principales resultados. México: Instituto Nacional de Estadística y Geografía.

Encuesta Nacional de Salud y Nutrición [ENSANUT]. (2012). Resultados Nacionales de la Salud adolescente [National adolescent health outcomes]. Cuernavaca, México: Instituto Nacional de Salud Pública.

Estrada, F., Campero, L., Suárez, L., Vara, E. D. L., \& González, G. (2017). Conocimientos sobre riesgo de embarazo y autoeficacia en hombres adolescentes: apoyo parental y factores escolares. Salud Pública de México, 59, 556-565.

Fishbein, M. (2000). The role of theory in HIV prevention. Aids Care, 12 (3), 273- 278

González, G. C., Rojas, M. R., Hernández, S. M. \& Olaiz, F.G. (2005). Perfil del comportamiento sexual en adolescentes mexicanos de 12 a 19 años de edad. Resultados de la ENSA 2000 [Profile of sexual behavior in Mexican adolescents 12 to 19 years of age. Results of ENSA 2000]. Salud Pública de México, 47, 3, 209- 218.

González, R. Vassileva, J. Bechara, A., Grbesic, S., Sworowski, L. Novak, R., Nunnally, G. \& Hielen, M. (2005). The influence of executive func- 
tions, sensation seeking, and HIV serostatus on the risky sexual practices of substance-dependent individuals. Journal of the International Neuropsychological Society, 11, 121- 131.

Hansen, E. B. \& Breivik, G. (2001). Sensation seeking as a predictor of positive and negative risk behaviour among adolescents. Personality and Individual Differences, 30 (4), 627-640. DOI: 10.1016/S01918869(00)00061-1

Horvath, P. \& Zuckerman, M. (1993). Sensation seeking, risk appraisal, and risky behavior. Personality and Individual Differences, 14, $41-52$.

Hoyle, R. H., Fejfar, M. \& Miller, J. (2000). Personality and sexual risk taking: A quantitative review. Journal of Personality, 68 (6), 1203- 12531.

Jiménez, G. S., Andrade, P. P., Betancourt, O. D. \& Palacios, D. J. (2007). Habilidades de comunicación en la conducta sexual de riesgo en jóvenes. [Communication skills in sexual risk behavior in young people]. Revista Intercontinental de Psicología y Educación, 9 (2), 147- 162.

Kalichman, S. \& Cain, D. (2004). A prospective study of sensation seeking and alcohol use as predictors of sexual risk behavior among men and woman receiving sexually transmitted clinic services. Psychology of Addictive Behaviors, 18, 367- 373.

Koniak-Griffin, D. \& Stein, J. (2006). Predictors of sexual risk behaviors among adolescent mothers in a human immunodeficiency virus prevention program. Journal of Adolescent Health, 38 (3), 297 e1-.e11.

Luszczynska, A., Sheng, C. D., Mallach, N., Pietron, K., Mazurkiewicz, M. \& Schwarzer, R. (2010). Intentions, planning, and self-efficacy predict physical activity in Chinese and Polish adolescents: Two moderated mediation analyses. International Journal of Clinical and Health Psychology, 10 (2), 265-278

Lindberg, C. E. (2000). Knowledge, Self-Efficacy, Coping, and Condom Use Among Urban Women. Journal of the Association of Nurses in AIDS care, 11 (5), 80-90.

Noar, S., Zimmerman, R., Palmgreen, P., Lustria, M. \& Lee, H. M. (2006). Integrating personality and psychosocial theoretical approaches to understanding saber sexual behavior: Implications for message design, Health Communication, 19 (2), 165- 174.

O'Leary, A., Jemmott, L. S. \& Jemmott III, J. B. (2008). Mediation Analysis of an Effective Sexual Risk-Reduction Intervention for Women: The Importance of Self-Efficacy. Health Psychology, 27 (2), Suppl 1, S180S184.

Palacios, D. J. (2010). Autoeficacia e intención conductual del consumo de tabaco en adolescentes: validez factorial y relación estructural. [Self efficacy and behavioral intention of tobacco use in adolescents: factorial validity and structural relationship]. Adicciones, 22 (4), 325-330.

Palacios, D. J. (2011). Las conductas de riesgo del adolescente. [Adolescent risk behaviors]. México: Centro de Investigación e Innovación Biopsicosocial, AC.

Palacios, D. J. (2015a). Propiedades psicométricas del inventario de búsqueda de sensaciones para adolescentes en México (IBS-Mx). Psychometric Properties of the Sensation Seeking Inventory for Adolescents in Mexico (IBS-Mx)]. International Journal of Psychological Research, 8 (1), 46-60.

Palacios, D. J. (2015b). Estimación psicométrica de la escala de autoeficacia ante conductas de riesgo para adolescentes en México. [Psychometric estimation of the self-efficacy scale for adolescent risk behaviors in Mexico]. Psychosocial Intervention, 1, 1-7.

Palacios, D. J., Andrade, P. P. \& Bravo, F. M. (2008). Consumo de alcohol $\mathrm{y}$ conducta sexual de riesgo en adolescentes. [Alcohol drinking and risky sexual behavior in adolescents]. En: Rivera, A. S., Díaz-Loving, R. Sánchez, A. R., \& Reyes, L. I. (Eds.). La Psicología Social en México (pp. 267- 272), Vol. 12, México: AMEPSO.

Palacios, D. J., Bravo, F. M. \& Andrade, P. P. (2007). Consumo de alcohol y conducta sexual de riesgo en adolescentes. [Alcohol consumption and risky sexual behavior in adolescents]. Psychology International, 18 (4), 1-13.

Palacios, D. J. \& Bustos, A. M. (2012a). Modelo de autoeficacia y habilidades ambientales como predictores de la intención y disposición proambiental en jóvenes. [Model of self-efficacy and environmental skills as predictors of intention and pro-environmental disposition in young people]. Revista Intercontinental de Psicología y Educación, 14 (2), 143- 163.

Palacios, D. J. \& Bustos, A. M. (2012b). La teoría como promotor para el desarrollo de intervenciones psicoambientales. [The theory as a promo- ter for the development of psycho-environmental interventions]. Psychosocial Intervention, 21 (3), 245- 257.

Palacios, D. J. \& Bustos, A. M. (2013). Validez factorial de la autoeficacia ambiental y su influencia estructural sobre la conducta proambiental en jóvenes. [Factor validity of environmental self-efficacy and structural influence on pro-environmental behavior in young people]. Revista Iberoamericana de Evaluación en Psicología, 35 (1), 95-111.

Palacios, D. J. \& Cañas, M. J. (2010). Características psicosociales asociadas al consumo de alcohol, tabaco y drogas en adolescentes de Chiapas. Psychosocial characteristics associated with alcohol, tobacco and drug use among adolescents in Chiapas]. Revista Psicología Iberoamericana, 18 (2), 27- 36.

Palacios, D. J. \& Parrao, L. M. (2010). Intención, habilidades y eficacia para predecir el uso del condón. [Intention, skills and efficacy to predict condom use]. En: Rivera, A. S., Díaz-Loving, R. Sánchez, A. R., y Reyes, L. I. (Eds.). La Psicología Social en México (pp. 267- 272), Vol. 13 , México: AMEPSO.

Palacios, D. J. \& Ramírez, A. V. (2016). Estudio comparativo de la autoeficacia saludable en las conductas alimenticias de riesgo. [Comparative study of healthy self-efficacy in risky dietary behaviors]. Revista Psicología Iberoamericana, 24 (2), 17-25.

Palacios, D. J., Ramírez, A. V. Anaya, M., Hernández \& Martínez, M. R. (2017). Evaluación psicométrica de la escala de autoeficacia del consumo alimenticio. [Psychometric evaluation of the self-efficacy scale of food consumption]. Revista Chilena de Nutrición, 44 (1), 95-102. DOI 10.4067/S0717-75182017000100013

Palacios, D. J., Sánchez, T. B. \& Andrade, P. P. (2010). Intento de suicidio y búsqueda de sensaciones en adolescentes. [Attempted suicide and sensations seeking in adolescents]. Revista Intercontinental de Psicología $y$ Educación, 12 (1), 53-75.

Roberti, J. W. (2004). A review of behavioral and biological correlates of sensation seeking. Journal of Research in Personality, 38, 256 - 279.

Robles, M. S., Piña, L. J., Frías, A. B., Rodríguez, C. M., Barroso, V. R. \& Moreno, R. D. (2014). Predictores de conductas relacionadas con el uso inconsistente de condón en estudiantes universitarios. Psicología Salud, 16(1), 71-78

Rodríguez, D. M., Paniagua, B. R., Montijo, S. R., Villegas, R. B., Arroyo, B. F., \& Cervantes, M. R. (2008). Características del debut sexual de los adolescentes y determinantes del uso consistente del condón desde el análisis contingencial. Psicología y Salud, 18(2), 207-225.

Rosenbloom, T. (2003). Risk evaluation and risky behaviors of high and low sensation seekers. Social Behavior and Personality, 31, 375- 386.

Sayles, J., Pettifor, A., Wong, M., MacPhail, C., Lee, S., Hendriksen, E., Rees, H. \& Coates, T. (2006). Factors associated with self-efficacy for condom use and sexual negotiation among South African youth. Journal of Acquired Immune Deficiency Syndromes, 43(2), 226-33.

Sanderson, C. A. \& Yopyk, D. J. (2007). Improving Condom Use Intentions and Behavior by Changing Perceived Partner Norms: An Evaluation of Condom Promotion Videos for College Students. Health Psychology, 26 (4), 481-487.

Spitalnick, J., DiClemente, R., Wingood, G., Crosby, R., Milhausen, R., Sales, J., McCarty, F., Rose, E. \& Younge, S. (2007). Brief report: Sexual sensation seeking and its relationship to risky sexual behaviour amon African- American adolescent females. Journal of Adolescence, 30, 165173

Secretaría de Salud (2011). Reglamento de la Ley General de Salud en Materia de Investigación para la Salud. [Regulation of the General Law of Health in Research for Health]. Recuperado Febrero 15, 2017, de http://www.salud.gob.mx/unidades/cdi/nom/compi/rlgsmis.html

Torres, M. K. \& Díaz- Loving, R. (1999). Un modelo integral predictivo del uso del condón. [A predictive model of condom use]. En: DíazLoving, R. \& Torres, M. K. (Coords.). Juventudy SID A: Una visón psicosocial. México: Porrúa.

Wilson-Barlow, L., Hollins, T. \& Clopton, J. (2014). Construction and validation of the healthy eating and weight self-efficacy (HEWSE) scale. Eating Behaviors, 15, 490-492.

Zuckerman, M. (1971). Dimensions of sensation seeking. Journal of Consulting and Clinical Psychology, 36, 4552 
Zuckerman, M. (1979). Sensation seeking: Beyond the optimal level of arousal. Hillsdale, New Jersey: LEA.

Zuckerman, M. (1994). Behavioral expressions and biosocial bases of sensation seeking. United States of America: Cambridge University.
Zuckerman, M. (2007). Sensation seeking and risky behavior. Washington: American Psychological Association.

Zuckerman, M. \& Kuhlman, D. M. (2000). Personality and risk taking: Common biosocial factors. Journal of Personality, 68, 999- 1029. 